Piśmiennictwo zakonne $w$ dobie staropolskiej, red. Magdalena Kuran, Katarzyna KaczorScheitler i Michał Kuran, przy współpracy Dawida Szymczaka, Łódź 2013.

Katarzyna Kaczor-SCheitLer ${ }^{1}$

Uniwersytet Łódzki

\title{
Idea zastosowania zmysłów w medytacjach o Męce Pańskiej na przykładzie rękopisu przechowywanego w Archiwum Norbertanek Zwierzynieckich
}

Klasztor Norbertanek w Krakowie na Zwierzyńcu powstał między 1149 a 1164 rokiem. Ufundowany został przez Jaksę z Miechowa (zm. 1176), który wywodził się z rodu Gryfitów i należał do czołowych przedstawicieli możnowładców małopolskich ${ }^{2}$. Norbertanki zwierzynieckie sprowadzone zostały do Polski z Doksan koło Pragi około 1146 roku za sprawą Agnieszki, żony Władysława Wygnańca³.

Do głównych elementów duchowości norbertanek, żyjących według reguły św. Augustyna, należą: chwała i uwielbienie Boga, miłość do Chrystusa w Eucharystii jako Ofiary, miłość do Matki Bożej Niepokalanej i Kościoła oraz gorliwość o zbawienie dusz przez praktykowanie modlitwy i pokuty ${ }^{4}$.

Wśród norbertanek zwierzynieckich szczególną świętością odznaczały się Judyta Krakowianka (zm. 1255) i Zofia Lubomirska (zm. 1606), których imiona zapisane zostały przez polskich pisarzy (Piotra Hiacynta Pruszcza, Floriana Jaroszewicza, Daniela Antoniego Józefa Kraszewskiego, opata witowskiego) oraz w kronikach klasztoru. Świadectwo świątobliwości dała też przykładem swojego życia bł. Bronisława, uro-

\footnotetext{
${ }^{1}$ Katarzyna Kaczor-Scheitler (ur. 1972) — dr nauk humanistycznych, adiunkt w Katedrze Literatury Staropolskiej i Nauk Pomocniczych Uniwersytetu Łódzkiego. Absolwentka filologii polskiej Wyższej Szkoły Pedagogicznej im. KEN w Krakowie (1996), gdzie ukończyła również Studium Dziennikarskie. Doktorat uzyskała w Uniwersytecie Łódzkim (2003) na podstawie rozprawy Mistycyzm hiszpański w piśmiennictwie polskich karmelitanek XVII i XVIII wieku. Zajmuje się problematyką religijną w literaturze dawnej. Jej publikacje zamieszczone są w czasopismach (m.in. w „Ruchu Literackim”, „Przeglądzie Powszechnym”, „Actach Universitatis Lodziensis. Folia Litteraria Polonica”, „Pracach Polonistycznych”) i w pracach zbiorowych. Jest autorką 2 książek: Mistycyzm hiszpański w pismiennictwie polskich karmelitanek XVII i XVIII wieku (Łódź 2005) oraz Marianna Marchocka a św. Teresa z Avila (Poznań 2009).

${ }^{2}$ Zob. W. Knapiński, Norbertanie i Norbertanki, [w:] Encyklopedia kościelna podtug Teologicznej Encyklopedii Wetzera $i$ Weltego, wyd. M. Nowodworski, t. 16, Warszawa 1885, s. 341-342; A. Żak, Norbertanie i Norbertanki w Polsce, „Przegląd Powszechny”, R. 37: 1920, t. 147-148, s. 321-328; J. Bazydło, Jaksa z Miechowa, [w:] Encyklopedia katolicka, red. S. Wielgus, J. Duchniewski, M. Daniluk i in., t. 7, Lublin 1997, szp. 699-700.

${ }^{3}$ Inne źródła podają, że do Polski norbertanki przybyły w 1162 roku — zob. M. Konieczny, Norbertanki, [w:] Encyklopedia katolicka, red. E. Gigilewicz, t. 13, Lublin 2009, szp. 1391; Hasło: Norbertanie, [w:] Religia. Encyklopedia, red. T. Gadacz, B. Milerski, t. 7, Warszawa 2003, s. 343.

${ }^{4}$ M. Konieczny, $d z$. cyt., szp. 1391.
} 
dzona w pierwszych latach XIII wieku (przyjmuje się rok 1203/1204), zmarła w 1259 roku, córka Stanisława Odrowąża i Anny Prandocianki herbu Gryf oraz prawnuczka Jaksy Gryfity z Miechowa. Spokrewniona była z rodem Odrowążów — kuzynami: Jackiem i Czesławem oraz stryjem Iwonem, biskupem krakowskim ${ }^{5}$ O żarliwej pobożności Bronisławy, ćwiczeniu się w ustawicznej modlitwie, rozmyślaniu Męki Pańskiej, umartwieniu i pokorze pisał w Fortecy monarchów i catego Królestwa Polskiego Piotr Hiacynt Pruszcz, który jako pierwszy nazwał ją błogosławioną̧ ${ }^{6}$.

Do zasłużonych norbertanek zwierzynieckich doby baroku należała ksieni Dorota Kątska (1558-1643) herbu Brochwicz , której dokonania względem zgromadzenia były znaczne. Za jej czasów konwent zwierzyniecki przeżywał okres największego rozkwitu, o czym świadczył spory jego przyrost liczebny — „półtorasta panienek” (150 nowych zakonnic), będący jej zasługą ${ }^{9}$. Wzrost powołań zakonnych w okresie potrydenckim był zjawiskiem powszechnym, jednak ksieni Dorota Kątska miała w tym istotny udział ${ }^{10}$.

$\mathrm{Na}$ życie duchowe norbertanek krakowskich duży wpływ miały siostry przełożone oraz spowiednicy. Innym środkiem, który odegrał istotną rolę w formacji duchowej zakonnic, była lektura religijna. Służyła ona do postępu w doskonałości, stanowiła pomoc w modlitwie, także w pokrzepieniu ducha i serca. Norbertanki wczytywały się w Pismo Święte ${ }^{11}$, sięgały po polski przekład Psałterza ${ }^{12}$, a także po inne cenne dzieła znajdujące się w zbiorach biblioteki zakonu.

Archiwum Norbertanek Zwierzynieckich (dalej: ANZ) przechowuje wiele ascetyczno-mistycznych starodruków z czasów ksieni Doroty Kątskiej. W posiadaniu

\footnotetext{
${ }^{5}$ K. Górski, Ród Odroważów w wiekach średnich, „Roczniki Polskiego Towarzystwa Heraldycznego”, Lwów 1928, t. 1, z. 8, s. 17: „Bronisława, która niewątpliwie była ze św. Jackiem spowinowacona”. B. Przybyszewski twierdzi, że żadne źródło nie wskazuje nazwiska Bronisławy, jedynie informację, że pochodziła ze szlacheckiego rodu - B. Przybyszewski, Bronisława bt., [w:] Hagiografia polska, Poznań 1971, s. 205. Zob. T. Petrycówna, Kronika, rkps Archiwum Norbertanek Zwierzynieckich (dalej: ANZ), rkps 42, s. 19.

${ }^{6}$ Zob. P. H. Pruszcz, Forteca monarchów i całego Królestwa Polskiego duchowna, z Żywotów Świętych tak już kanonizowanych i beatyfikowanych, jako też świątobliwie żyjacych patronów polskich... do druku podana, Kraków 1737, s. 107-109.

${ }^{7}$ A. Boniecki, Herbarz polski, cz. 1: Wiadomości historyczno-genealogiczne o rodach szlacheckich, t. 9, Warszawa 1906, s. 368; K. Niesiecki, Herbarz polski, wyd. J. N. Bobrowicz, t. 5, Lipsk 1840, s. 55-56; B. Paprocki, Herby rycerstwa polskiego, Kraków 1858, s. 721; S. Uruski, Rodzina. Herbarz szlachty polskiej, t. 6, Warszawa 1909, s. 274.

${ }^{8}$ T. Petrycówna, dz. cyt., s. 22.

${ }^{9} \mathrm{D}$. Kątska odznaczała się przedsiębiorczością i zmysłem organizacyjnym, czego dowodem są liczne prace budowlane, którymi zarządzała. W latach 1620-1622 przystąpiła do rozbudowy kościoła św. Salwatora w Krakowie na Zwierzyńcu, wzbogacając go o nowe ołtarze. Z jej inicjatywy w latach 1633-1643 wzniesiony został kościół i klasztor św. Norberta w Krakowie, dokąd przeniosła ona 20 zakonnic z konwentu zwierzynieckiego. Zob. Rkps ANZ, sygn. 44, s. 95-96; A. Dygat, A. Rybak, Odrodzenie klasztoru zwierzynieckiego za ksieni Doroty Kątskiej (1591-1643), „Nasza Przeszłośc” 1977, t. 47, s. 186.

${ }_{10}$ Zob. A. Dygat, Kątska (Kącka, Kontska) Dorota, [w:] Polski stownik biograficzny, red. B. Leśnodorski

i in., t. 12, Wrocław 1966-1967, s. 309; A. Dygat, A. Rybak, dz. cyt., s. 191, 204-205.

${ }^{11}$ Biblia, to jest księgi Starego i Nowego Testamentu, przekład Jakuba Wujka, Kraków 1599, druk. Łazarzowa.

${ }^{12}$ Psatterz Dawidów przetożony przez ks. Jakuba Wujka, teraz znowu na żadanie wielu panien tacińskiego jezyka nie umiejących, a Psałterz mówić pragnących... przedrukowany, Kraków 1626.
} 
konwentu znajdują się również kodeksy rękopiśmienne autorstwa zwierzynieckich zakonnic. W wieku XVII znaczna część twórczości literackiej pozostawała w manuskryptach i tylko w tej postaci wchodziła w obieg czytelniczy. Wiele też tekstów przetrwało $\mathrm{w}$ zbiorach rękopiśmiennych jako utwory anonimowe ${ }^{13}$. Natomiast spośród znanych z imienia autorek norbertańskich, które pozostawiły po sobie twórczość rękopiśmienną, wskazać należy Teresę Petrycównę i Krystynę Szembekównę. Teresa Petrycówna (ok. 1629-1700), córka Jana Innocentego Petrycego (1592-1641) ${ }^{14}$, profesora Akademii Krakowskiej, lekarza i rajcy krakowskiego, i wnuczka Sebastiana Petrycego (zm. 1626) ${ }^{15}$, także profesora Akademii, pionierskiego tłumacza na język polski oraz komentatora Arystotelesa i Horacego ${ }^{16}$, również lekarza królewskiego, była autorką rękopiśmiennych Medytacyi ${ }^{17}$, będących wyrazem jej żarliwej pobożności, oraz Kroniki zgromadzenia ${ }^{18}$; dokonała też przekładu z łaciny żywotu Józefa Hermana ${ }^{19}$. Spod pióra Krystyny Szembekówny (ok. 1669-1742), siostry biskupa krakowskiego, wyszedł siedemnastowieczny Modlitewnik ${ }^{20}$, będący zbiorem różnorodnych pod względem tematycznym i strukturalnym modlitw oraz medytacji.

Na uwagę zasługuje też anonimowy kodeks rękopiśmienny z 1662 roku, Kontemplacyja męki i śmierci Chrystusa Pana i Odkupiciela naszego ku naśladowaniu i używaniu dusze nabożnej z inszemi bardzo uciesznemi wedtug czasu kontemplacyjami i naukami, przechowywany w ANZ ${ }^{21}$, którego medytacje pasyjne, omawiane z perspektywy zastosowania zmysłów, staną się przedmiotem niniejszego artykułu. Na podstawie manuskryptu trudno o ustalenia dotyczące jego autorstwa, tym bardziej że zawarte w nim teksty pisane są różnym charakterem pisma. Wolno jedynie wysunąć tezę, że autorki kodeksu należały do zakonu norbertanek zwierzynieckich.

Rękopis ten, oprócz rozmyślań poświeconych męce i śmierci Chrystusa, zawiera także Medytacyje o Zmartwychwstaniu Pańskim, Medytacyje o Duchu Świętym, Medytacyje na dzieńn Narodzenia Pańskiego, Medytacyje o godach w Kanie Galilejskiej, Medytacyje o pustyni Chrystusa Pana. Znajdziemy tu również między innymi składający się z ośmiu rozdziałów tekst $O$ wnętrznej rozmowie Pana Boga z człowiekiem, także Pożytki z modlitwy wnętrznej abo bogomyślności oraz Kazanie na dzień chwalebnego Wniebowzięcia Naświętszej Panny Królowej Anielskiej. W dalszej części rękopisu umieszczone są: Żywot św. Norberta oraz cykl ośmiu Rozmyślań jemu poświęconych (Rozmyślanie

\footnotetext{
${ }^{13}$ A. Karpiński, Tradycja tekstu w „wieku rękopisów”. Uwagi o rękopiśmiennym funkcjonowaniu dzieta literackiego, [w:] Staropolska kultura rękopisu, red. H. Dziechcińska, Warszawa 1990, s. 27-42.

${ }^{14}$ Zob. L. Hajdukiewicz, Petrycy Jan Innocenty, [w:] Polski stownik biograficzny, red. H. Markiewicz, t. 25, Wrocław 1980, s. 701-703.

${ }^{15}$ Zob. H. Barycz, Petrycy Sebastian z Pilzna, [w:] tamże, s. 703-707.

${ }^{16}$ Zob. K. Estreicher, Bibliografia polska, t. 24, Kraków 1912, s. 208-211.

${ }^{17}$ T. Petrycówna, Medytacje (XVII w.), rkps ANZ, sygn. 595, ss. 292.

${ }^{18}$ Taż, Kronika, rkps ANZ, sygn. 42.

${ }^{19}$ K. Kramarska-Anyszek, Dzieje Klasztoru PP. Norbertanek w Krakowie na Zwierzyńcu do roku 1840, „Nasza Przeszłość” 1977, t. 47, s. 91.

${ }^{20}$ K. Szembek, Modlitewnik (z XVII w.), rkps ANZ, sygn. 589.

${ }^{21}$ Kontemplacyja Męki i śmierci Chrystusa Pana i Odkupiciela naszego ku naśladowaniu i używaniu dusze nabożnej z inszemi bardzo uciesznemi wedtug czasu kontemplacyjami i naukami, pisana roku Pańskiego 1662, rkps ANZ, sygn. 594. Rękopis ten odnotowują A. Dygat, A. Rybak, dz. cyt., s. 199.
} 
przez Oktawę św. Norberta z żywota jego, O powołaniu św. Norberta, O dziwnej odmianie Ojca św. Norberta, O tym, co Pan Bóg odpowiada Norbertowi św. o strzeżenie się grzechu, O pokoju, który zaleca Pan Bóg św. Norbertowi, O pokorze świętej i ubóstwie Norberta św., O szczerej mitości Bożej i inszych cnotach Ojca św. Norberta, O zacności zakonu świętego premonstrateńskiego).

Zawarte w manuskrypcie medytacje o tematyce pasyjnej nakłaniają do rozważań Męki Pańskiej także przy zastosowaniu zmysłów (applicatio sensuum), metody wprowadzonej przez św. Ignacego Loyolę̨, oraz współdziałaniu trzech władz duchowych: pamięci, rozumu i woli w rozważaniu wydarzeń z życia Chrystusa i tajemnic wiary. Według św. Ignacego Loyoli: „Pamięć przypomina treść danej prawdy wiary lub przebieg rozważanej z życia Jezusa; rozum rozważa i wyciąga wnioski, a wola wzbudza odpowiednie uczucia i czyni decyzje"23.

$\mathrm{Na}$ temat koncepcji pięciu zmysłów duchowych pisał Orygenes, który sformułował tezę, że oprócz pięciu zmysłów cielesnych, mamy tyle samo duchowych, nazywanych zmysłami człowieka wnętrznego, boskimi, zmysłami serca ${ }^{24}$. „Dynamika ich rozwoju i wyostrzania zależna jest od postępu duchowego oraz stopniowego wyzwalania się spod dominacji zmysłów cielesnych" 25 . Kontynuatorem koncepcji zmysłów duchowych był św. Bonawentura, który uważał, że zmysły zakorzenione są w cnotach teologalnych wzrok i słuch duchowy w wierze, powonienie w nadziei, smak i dotyk w miłości ${ }^{26}$.

Według św. Ignacego Loyoli, posługujący się podczas modlitwy pięcioma zmysłami doświadczają scen z życia Chrystusa oraz przeżywają cnoty Matki Bożej. Medytacja zakłada więc związek z rzeczywistością, którą należało „zastosować” (applicare) podczas ćwiczeń duchowych. Za pomocą wyobraźni, analogicznie do poznania zmysłowego, adept medytacji powinien wpatrywać się w osoby, wsłuchiwać w ich słowa, dotykać miejsc, zmysłem węchu i smaku doświadczać duchowych tajemnic. Św. Ignacy Loyola nakłaniał medytujących, by:

Widzieć osoby wzrokiem wyobraźni [...] Słuchać uszami wyobraźni, co mówią lub co mówić mogą [...] Wąchać i smakować zmysłem węchu i smaku w wyobraźni nieskończoną słodycz i łagodność Bóstwa [...] Dotykać zmysłem dotyku, tak np. obejmować i całować miejsca, gdzie te osoby święte stawiają kroki lub siedzą, a zawsze starając się o jakiś pożytek z tego.

(I. Loyola, Ćwiczenia duchowne, pp. 122-125) ${ }^{27}$

\footnotetext{
${ }^{22} \mathrm{O}$ zastosowaniu zmysłów (applicatio sensuum) zob.: Św. I. Loyola, Pisma wybrane, oprac. M. Bednarz SJ, t. 2, Kraków 1968, s. 26, 35-36, 73, 116-117, 126, 128, 306; K. Mrowcewicz, Polska poezja medytacyjna XVI stulecia —od Dantyszka do Grabowieckiego, [w:] Nurt religijny w literaturze polskiego średniowiecza i renesansu, red. S. Nieznanowski i J. Pelc, Lublin 1994, „Religijne Tradycje Literatury Polskiej”, t. 4, s. 333-363; E. Poprawa-Kaczyńska, Ignacjański "modus meditandi” w kulturze religijnej późnego baroku. Rekonesans, [w:] Religijność literatury polskiego baroku, red. Cz. Hernas, M. Hanusiewicz, Lublin 1995, „Religijne Tradycje Literatury Polskiej”, t. 5, s. 259-270.

${ }^{23}$ Św. Ignacy Loyola, dz. cyt., s. 24.

${ }^{24}$ A. Louth, Początki mistyki chrześcijańskiej (od Platona do Pseudo-Dionizego Areopagity), przekł. H. Bednarek, Kraków 1997, s. 90.

${ }^{25}$ M. Hanusiewicz, Święte i zmystowe w poezji religijnej polskiego baroku, Lublin 1998, s. 130.

${ }^{26}$ J. Aumann, Zarys historii duchowości, przekł. J. Machniak, Kielce 1993, s. 165-166.

${ }^{27}$ Św. I. Loyola, dz. cyt., s. 126.
} 
Struktura medytacji pasyjnych w rękopisie Kontemplacyja Męki i śmierci Chrystusa Pana w niczym nie przypomina jednak ignacjańskiego podziału ćwiczeń przewidzianych na cztery tygodnie czy w wersji skróconej dziesięcio- lub ośmiodniowych. W obrębie każdej medytacji, których jest pięćdziesiąt, dają się wydzielić zazwyczaj trzy punkty (rzadziej dwa, cztery czy pięć).

Anonimowa autorka wielokrotnie posługuje się w medytacjach metodą zastosowania pięciu zmysłów (applicatio sensuum), polegającą na umartwieniu zmysłów zewnętrznych przez wewnętrzne. Odzwierciedlenie tej idei obrazuje już druga medytacja Kontemplacyi Męki i śmierci Chrystusa Pana, ukazująca drogę Chrystusa do Ogrójca. Kieruje się tutaj do adepta następujące zalecenia:

I. Patrzyć oczyma dusze na Chrystusa, który z miasta jerozolimskiego idzie z uczniami swemi. Kto jest ten, co wychodzi? Nie inny, jedno który być się światłością powiedział, kiedy światłość odchodzi z miejsca jakiego, następują ciemności [...] Patrzyć na Chrystusa jako na Dawida idącego boso, smutno $\mathrm{z}$ miasta $[\ldots]$.

II. Po wtóre, słuchać tu, co Chrystus mówił do uczniów: „Smutna dusza moja”. I słuchać głosu Onego, którym do mnie mówi: „Oto ja smucę się, abyś ty na wieki pociech zażywała” [...].

III. Wonią oną wnętrzną kosztować gorzkości smutków Zbawiciela mego, któremi jako ofiarą miry błagany Bóg Ociec był [...].

IV. Całować onę drogę, po której Chrystus Pan chodził. Całowanie to ma być wnętrzne, życząc, żebyś się na ten czas obrócić była mogła w ziemię abo kamienie [...].

(Wtóra medytacyja o tejże drodze. Powtórzenie przez zmysty wnętrzne ${ }^{28}$

Rozmyślanie to przebiega według pewnego porządku. Zwraca się uwagę na umiejscowienie (wyobrażenie) przedmiotu medytacji (compositio loci). Ustala się miejsce, jakby się je widziało. Jest nim droga z Jerozolimy do Ogrójca. Rozważa się także, kto kroczy tą drogą. Jest to Jezus Chrystus ze swoimi uczniami. Właściwe rozmyślanie polega na odtworzeniu, z zastosowaniem zmysłu wzroku, słuchu, powonienia i dotyku, treści rozważanego wydarzenia. Każdy punkt medytacji wieńczy modlitewna rozmowa człowieka z Bogiem (colloqium). Dla przykładu wskażemy dwie modlitwy medytującego: „O prawdziwy Dawidzie, Chryste, Panie mój, obym ja była w towarzystwie na ten czas Twoim [...] O, dobry Jezu, Tyś jako Ociec, w pocie robisz, abyśmy dzieci z dziedzictwa Twego zażywali i weselili się". Ujawniający się adept rozmyślań nie jest skonkretyzowany; jest nim każda dusza ludzka rozważająca tajemnice pasyjne w celu wewnętrznego doskonalenia się.

Ideę zastosowania zmysłów obrazuje Medytacyja o Męce Pańskiej. Przez zmysty o wylaniu krwie w Ogrójcu, w której ma miejsce pięciopunktowe rozważanie konania Jezusa w Ogrójcu aż do płynącego z Jego ciała krwawego potu. Krew Chrystusa jest nierozerwalnie związana „ze zbawczą ofiarą, oczyszczeniem z grzechów, pojednaniem z Bogiem, zbawieniem i odkupieniem ludzi" ${ }^{29}$, stąd autorka zachęca, by przedmiotem rozmyślań był Chrystus przelewający swą krew za ludzkie grzechy. Każdy punkt

\footnotetext{
${ }^{28}$ Wszystkie cytaty fragmentów medytacji pochodzą z kodeksu rękopiśmiennego: Kontemplacyja męki $i$ śmierci Chrystusa Pana....

${ }^{29}$ B. Szier-Kramarek, Krew Chrystusa, [w:] Encyklopedia katolicka, t. 9, Lublin 2002, szp. 1283.
} 
wieńczą „,afekty”, czyli wszelkie poruszenia bądź wzruszenia umysłu ${ }^{30}$ : „podziwienia”, to znaczy podziwu ${ }^{31}$, „uprzejmości” ${ }^{2}$, ufności, prośby i „żądzy”33, po czym następuje Rozmowa do krwie. W punkcie pierwszym nakazuje się, za pomocą zmysłu wzroku, „patrzeć” na krew Chrystusa, jaką wylał On ze swego świętego ciała. Fakt ten stał się okazją do głębszych rozmyślań oraz żarliwej czci złożonej Przenajdroższej Krwi. Wyraz temu dała autorka już na samym początku medytacji, rozważając okoliczności miejsca oraz wprowadzając pytania charakterystyczne dla rozmyślań: kim jest Ten, kto krew wylewa, dla kogo to czyni, jakim sposobem i za pomocą jakiego afektu. Mówi się zatem o krwi Chrystusa przelanej dla człowieka na okup za grzechy, wylanej z wielką miłością, ale i z boleścią. Podkreśla się doniosłe znaczenie owej krwi, która „cnotami Jego pokory i miłości ozdobiona była”. W „afekcie podziwienia” składa się hołd majestatycznemu Bogu, który swą przenajświętszą krew wylewa za "podłego”34 człowieka.

W punkcie drugim medytacji autorka przekonuje do uruchomienia zmysłu słuchu, umożliwiającego „usłyszenie” płynącej krwi Chrystusa. Nakazuje adeptowi „słuchać” również przelanego krwią głosu Odkupiciela, który zachęca człowieka do nawrócenia i złożenia z siebie ofiary. W punkcie trzecim, skłaniającym medytującego do pobudzenia zmysłu powonienia, mowa o odczuciu zapachu słodkiej Krwi Przenajświętszej. Autorka nawołuje do doświadczenia obecności tej woni w Eucharystii („Uważ jako wdzięczny jest zapach tej Krwie Przenajświętszej, którą przy ofierze mszy świętej ofiarujemy”). Punkt czwarty zawiera zachętę do „smakowania” obecnej w Najświętszym Sakramencie krwi Chrystusa:

IV. Smak i słodkość tej krwie i cnót, które się przy wylaniu pokazały. Smakować trzeba, także czuć słodkość krwie, która na ołtarzu w Sakramencie ofiarowana bywa.

(Medytacyja o Męce Pańskiej. Przez zmysty o wylaniu krwie w Ogrójcu)

W „afekcie prośby” znalazło się pragnienie zażywania krwi jako „przysmaku w cierpliwości”, czyli podoławszy dolegliwościom, przykrościom ${ }^{35}$, we wzgardzie i nędzy.

\footnotetext{
${ }^{30}$ Słowo 'afekt' ma kilka znaczeń: 1. wszelkie poruszenie lub wzruszenie umysłu; 2. namiętność; 3. miłość, skłonność, przywiązanie, chęć ku czemu, przychylność — zob. S. B. Linde, Stownik języka polskiego, wyd. 2 popr. i pomnożone, t. 1, Lwów 1854, s. 6.

${ }^{31}$ Podziwienie, podziw, spodziw, czyli dziw, dziwowanie się czemu — zob. tenże, Stownik języka polskiego, wyd. 2 popr. i pomnożone, t. 4, Lwów 1858, s. 259.

32 Uprzejmość, czyli szczerość, dobroć, łaskawość, szczera serdeczna chęć, życzliwość - zob. tenże, Stownik języka polskiego, wyd. 2 popr. i pomnożone, t. 6, Lwów 1860, s. 158.

33 Żądza, czyli siła przyrodzona w człeku i bydlętach, dobra z siebie sama; żądza, żądanie, pragnienie, chcenie, chęć, chuć - zob. tamże, t. 6, s. 745.

${ }^{34}$ Podły, czyli niewiele wart, niewielkiej ceny, niski, pospolity, prosty, błahy, nieszlachetny — zob. tenże, Stownik jezyka polskiego, t. 4, s. 225.

${ }^{35}$ Cierpliwość, czyli wydoływanie dolegliwościom, przykrościom; cierpliwy, cierpliwie — znoszący cierpienie, przykrość — zob. S. B. Linde, Stownik języka polskiego, t. 1, s. 305-306. Zob. też: Wydoływać, wydoływać - zdolnością wyrównać, zarównać, być równym, wydołać co? — być w stanie zrobienia, uczynienia (tenże, Stownik jezzyka polskiego, t. 6, s. 479); Wydoływać — czemu? co? — zdołać, podołać, być w stanie, zrobić co, dokazać czego, dać radę, sprostać (J. Karłowicz, A. Kryński, W. Niedźwiedzki, Stownik jezyka polskiego, wyd. fotooffsetowe, t. 7, Warszawa 1953, s. 844).
} 
Rozważania kończą się prośbą medytującego skierowaną do Chrystusa o możliwość współuczestnictwa w cierpieniu: „O, nasłodszy Jezu, daj mi czuć, coś Ty czuł, kiedyś tę krew przenadroższą wylewał”. W piątym punkcie mowa o tym, iż dusza ludzka pragnie „być obmytą”, przy użyciu zmysłu dotyku, krwią niewinnego Baranka. Medytacja kończy się modlitwą (Rozmowa do krwie) skierowaną do krwi Jezusa, który przelał ją za człowieka. W modlitewnym uniesieniu osoba medytująca wyraża chęć współodczuwania boleści Chrystusa, składa też deklarację przyjęcia Krwi Przenajświętszej podczas Eucharystii.

Ideę zastosowania zmysłów oddaje Medytacyja przez zmysty o ubiczowaniu Pańskim, w której wizualizowana jest ta scena. O biczowaniu Chrystusa, karze wymierzonej $\mathrm{Mu}$ przez Piłata, mowa w Ewangeliach zarówno w zapowiedziach Męki Pańskiej (Mt 20, 19; Mk 10, 34; Łk 18, 33), jak i w jej opisie (Mt 27, 26; Mk 15, 15; Łk 23, 16; J 19, 1) ${ }^{36}$.

Autorka w punkcie pierwszym medytacji nakazuje „patrzeć” za pomocą „oka wnętrznego" na obnażenie Chrystusa z szat, przywiązanie Go do słupa i biczowanie. W pełnym naturalistycznego opisu obrazie nakłania adepta do przyglądania się ranom „aż do kości otwartym” oraz krwi z nich płynącej.

O bólu Maryi uczestniczącej w scenie biczowania Chrystusa traktuje Medytacyja o tym, co czuła Panna Naświętsza, kiedy Syn Jej, Pan Jezus, byt biczowany. Przez zmysty. Autorka parafrazuje w tym miejscu wątki apokryficzne tekstu ascetycznego, ponieważ w Ewangeliach nie ma mowy o obecności Maryi podczas biczowania. Rozmyślanie rozpoczyna się nakłonieniem medytującego do przyglądania się „okiem wnętrznym” Maryi patrzącej na biczowanie swego jedynego Syna. W punkcie drugim autorka zaleca, by za pomocą zmysłu wewnętrznego „wsłuchiwać się” w słowa Matki, wychwalającej duchowe piękno Chrystusa („Słuchać onych głosów Jej serdecznych, abowiem widząc ono ciało zeszpecone, co miała mówić? Jedno: $O$, napiękniejszy między synami ludzkiemi«"). W punkcie kolejnym, nakazującym uruchomienie zmysłu dotyku, zachęca się modlącego do rozmyślania, w jaki sposób Maryja całowała „ziemię, kolumnę, bicze i rózgi” pokryte krwią Chrystusa.

Poddana rozważaniu „krwawa kolumna” stanowi paralelę ze słupem znanym z Księgi Wyjścia (Wj 13, 20-22), która opisuje Boga wyprowadzającego lud izraelski z niewoli egipskiej w dzień w słupie obłoku, żeby prowadzić naród, zaś w nocy w słupie ognia, by móc mu świecić. W części refleksyjnej rozmyślania ma miejsce zestawienie różniących się między sobą kolumn: tamta świeciła ogniem, ta zaś pokryta była krwią. Medytację wieńczą zalecenia skierowane do adepta, by zanosił modlitwy do „słupa” o światło podczas ziemskiej wędrówki oraz do krwi, by chroniła go przed mękami piekielnymi.

Do wątków apokryficznych należą także modlitwy Chrystusa podczas biczowania Go oraz obecność aniołów przy tej scenie. O uczestnictwie aniołów w czasie biczowania Chrystusa traktuje Medytacyja przez zmysty o aniołach świętych przy biczowaniu,

\footnotetext{
${ }^{36}$ J. Kudasiewicz, Biczowanie Chrystusa, [w:] Encyklopedia katolicka, red. F. Gryglewicz, R. Łukaszyk, Z. Sułowski, t. 2, Lublin 1985, szp. 514.
} 
których rolą było pocieszanie konającego. Już w punkcie pierwszym autorka nakazuje przyglądać się „okiem duszy” zastępom aniołów stojącym obok kolumny, przy której Zbawiciel był biczowany. Zaleca także przyjrzeć się ich zdumieniu z powodu niezmiernej miłości i ofiary Chrystusa względem grzesznego ludu. Punkt ten wieńczy „afekt podziwienia" dla Zbawiciela ze strony aniołów oraz prośba medytującego do nich skierowana o poruszenie serca człowieka, zdolnego do opłakiwania Pańskiej zelżywości.

Po biczowaniu Chrystusa założone Mu zostały przez żołnierzy Jego szaty, które zaczęły przysychać do zakrwawionego Jego ciała. Po czym zdarto je z Niego i ubrano w czerwony płaszcz, mający przypominać szaty królewskie. Do prawej Jego ręki włożono trzcinę, która miała oznaczać berło. Upleciono Mu także, mający symbolizować królewską godność, wieniec z ciernistego krzewu i włożono na głowę. Urągano $\mathrm{Mu}$ wówczas, naśmiewano się z Niego, popychano Go, pluto na Niego. W końcu ponownie przebrano Chrystusa w Jego własne szaty, by następnie Go wyprowadzić i ukrzyżować.

Wizualizację sceny ubierania się we własne szaty oddaje Medytacyja o tym, jako Pan ubiczowany w szaty się swe oblekt, w której autorka nakłania do uruchomienia zmysłu wzroku: „III. Patrz, jako się Chrystus Pan ubrał już w szateczki swoje. Oblókł się Pan, mówi prorok, w ozdobę". Ubogie odzienie Zbawiciela było wyrazem Jego miłości do człowieka, a przyobleczenie się w nie oznaczało Boskie wyniesienie, było kategorią duchową.

Koronowanie cierniem to czynność, jaka miała miejsce po biczowaniu Chrystusa. Cierniową koronę, jaką rzymscy żołnierze po ubiczowaniu Chrystusa włożyli na Jego głowę, wraz z krzyżem, włócznią, gwoźdźmi, gąbką, włącza się do relikwii Męki Pańskiej ${ }^{37}$. Zarówno jej kształt, jak i rodzaj ciernia pozostają przedmiotem nieustannych badań ${ }^{38}$. Warto jednak zaznaczyć, że w omawianych rozmyślaniach mowa o narzędziach Pasji w kontekście opisu literackiego, nie zaś w odniesieniu do realnych przedmiotów. Na skutek wizualizacji owych narzędzi łatwiej wyobrazić sobie przy użyciu zmysłów wymiar cierpienia. W Medytacyi przez zmysty z patrzenia na Pana ukoronowanego cirniem nakłania się adepta do „wpatrywania się” w głowę Chrystusa otoczoną cierniową koroną:

Patrzyć na głowę Chrystusa Pana cirniem skutą i ramiona, na oblicze Jego i oczy krwią zalane. Czytamy o Panu, że od płaczu z oczu Jego łzy padały, obacz teraz, jako nie łzy, ale krew z oczu Jego pada. [...] Któż tego przyczyną? - Cirnie, co głowę raniły.

(Medytacyja przez zmysty z patrzenia na Pana ukoronowanego cirniem)

Ewokowany stan, w jakim znalazł się Chrystus, w wyniku ran spowodowanych cierniami uciskającymi Jego głowę, prowadzi do wykładni rozszerzającej na ich temat. Osoba medytująca utożsamia się z cierniami, które symbolizują grzeszny lud.

\footnotetext{
${ }^{37}$ J. J. Kopeć, Przemiany ideowe pobożności pasyjnej na przykładzie kultu cierniowej korony Chrystusa, „Studia Theologica Varsaviensia”, R. 10: 1972, nr 2, s. 158.

${ }^{38}$ Zob. tamże; tenże, Cierniowa korona, [w:] Encyklopedia katolicka, red. R. Łukaszyk, L. Bieńkowski,

F. Gryglewicz, t. 3, Lublin 1985, szp. 474.
} 
Punkt kończy pokorna modlitwa błagalna o obmycie człowieka z wszelkich jego złych myśli oraz o przyozdobienie go krwią Chrystusową. W innym miejscu nakłania się adepta do „skosztowania słodkości cnót świętych, które się przy koronacyjej Pańskiej rozświeciły i rozkwitły”. Są one wyrazem niewypowiedzianej cierpliwości i nieogarnionej miłości Zbawiciela. Autorka, podpierając się wersetami z Pieśni nad Pieśniami („[...] mówiła ona Oblubienica: "Pójdę na górę mirry i kadzidła«”), uwydatnia ich jakość — wdzięczną woń. W symbolice biblijnej mirrę odnieść należy „do natury ludzkiej albo do śmierci Chrystusa, zapowiadanej przez mirrę, którą ofiarowali Mędrcy (Mt 2, 11), górę mirry (Golgota), wspomnianą w $\operatorname{PnP}(4,6)$, woreczek mirry, którą na piersiach nosi Oblubienica (PnP 1, 13) i która symbolizuje jej stałą pamięć o cierpieniach Chrystusa" ${ }^{39}$. By być zdolnym do wyrzeczeń i ćwiczeń ascetycznych oraz do przyjęcia męczeńskiej śmierci, należy nosić w sercu mirrę. Moc mirry jest więc podwójna; pod jej wpływem człowiek pragnie Boskiej miłości oraz Bóg kieruje swą miłość ku człowiekowi. Kadzidło zaś, jako symbol hołdu, oczyszczenia i przejaw obecności Boga, znamionowało także cnoty i dobre uczynki. Pięć ziarenek kadzidła umieszczanych w paschale miało przypominać o pięciu ranach Chrystusa oraz o wonnościach, które niewiasty niosły w poranek wielkanocny ${ }^{40}$. By doświadczyć mirry i kadzidła, cnót towarzyszących cierpiącemu Chrystusowi, kieruje się do medytującego słowa zachęty: „O, duszo moja, nie trzeba daleko pod górę chodzić, wstąp tylko na ten pałac, na którym Pana koronują. O, jako tam wiele mirry, jak wiele kadzidła najdziesz".

Kolejnym etapem męki Chrystusa jest wyprowadzenie Go przed czekający na zewnątrz tłum i przedstawienie Go: „Oto Człowiek” (J 19, 5), Ecce Homo. Są to słowa Piłata, jakie wypowiedział o Chrystusie po biczowaniu i cierniem koronowaniu. Wskazują one albo na Jego pokorę i niewinność albo — z nutą pogardy — na nieszkodliwość Jego działań ${ }^{41}$. Dla wielu komentatorów słowa te są nawiązaniem do Księgi Daniela $($ Dn 7,13$)$ i podkreślają godność Chrystusa jako Syna Człowieczego. Według innych, ma tu miejsce odniesienie do słów zawartych w prologu Ewangelii św. Jana, że "Słowo stało się ciałem i zamieszkało wśród nas" (J 1, 14). Są też i tacy komentatorzy, którzy pokazują tu celową analogię wobec rytuału koronacyjnego. Wybrany władca wyszedł przed naród i został przedstawiony: „Oto król wasz!” (J 19, 14) ${ }^{42}$.

O słowach Piłata: „Oto Człowiek” traktują zawarte w rękopisie: Medytacyja jako on Pitat okazawszy Pana Chrystusa do Żydów mówit: „Oto Cztowiek” oraz Medytacyja na te stowa "Oto Człowiek” jako je Panna Naświętsza styszała. Należy jednak podkreślić, że i w tym miejscu autorka parafrazuje wątki apokryficzne tekstu ascetycznego, gdyż

\footnotetext{
${ }^{39}$ Hasło: Mirra i aloes, [w:] D. Forstner OSB, Świat symboliki chrześcijańskiej, przekł. i oprac. W. Zakrzewska, P. Pachciarek, R. Turzyński, Warszawa 1990, s. 222.

${ }^{40}$ Hasło: Kadzidto, [w:] tamże, s. 217-222.

${ }^{41}$ J. Szlaga, Ecce Homo, Oto Człowiek, [w:] Encyklopedia katolicka, red. R. Łukaszyk, L. Bieńkowski,

F. Gryglewicz, t. 4, Lublin 1985, szp. 640.

${ }^{42}$ P. Łabuda, Jezus jako król w czwartej Ewangelii „To ty powiedziateś, że jestem królem” (J 18, 37), „Seminare", t. 24: 2007, s. 89.
} 
Ewangelie pozbawione są wzmianki o obecności Maryi podczas sądu Piłata. O potrzebie zastosowania zmysłów mowa w drugiej medytacji, w której zaleca się adeptowi uruchomienie zmysłu wzroku:

I. Patrzyć okiem wnętrznym na błogosławioną Pannę, jako ona na Syna swego w onej żałobnej postaci patrzyła, kiedy Go Piłat Żydom pokazał. Widziała Go w onej strasznej koronie na głowie, ręce mając opak związane, w ręku trzcinę położoną, twarz wszytkę zsiniałą i od bicia napuchłą, i oszpeconą krwią i plwocinami, oczy zalane łzami, włosy na głowie potargane. Słyszała i one słowa od Piłata: „Oto Człowiek".

(Medytacyja na te stowa „Oto Człowiek”, jako je Panna Naświętsza styszała)

W punkcie pierwszym autorka nakazuje przyglądać się za pomocą „oka wnętrznego" Maryi, która z żalem patrzyła na Syna, wyprowadzonego przez Piłata przed tłum. Zwraca uwagę pełen naturalizmu opis tej sceny, ukazującej drastyczny obraz umęczonego Zbawiciela. W punkcie drugim zaleca się poddać rozważaniu „słowa wnętrzne” Syna oraz Jego Matki wypowiadane w tych okolicznościach. Kolejny punkt zawiera wezwanie do uruchomienia zmysłu smaku, za pomocą którego można wyobrazić sobie, w jaki sposób Maryja czuła „słodkość” cnót Chrystusa, takich jak: pokora, ubóstwo, łaskawość, cierpliwość i miłość, w obliczu krzywd, których doznał. Mowa tu też o „wonnościach” owych cnót, jakimi powinna „pachnieć” dusza ludzka, skoro nieustannie się nimi „bawi”, czyli je rozważa („O, duszo moja, która bawisz się tak wielą wonnościami cnót, jakoż ich nie nabierzesz”).

O ukrzyżowaniu Chrystusa czytamy we wszystkich Ewangeliach, które w sposób szczegółowy podają okoliczności tego wydarzenia. Autorka Kontemplacyi Męki $i$ śmierci Chrystusa Pana scenie ukrzyżowania poświęciła aż pięć rozmyślań. Wśród nich znalazły się: Medytacyja o ukrzyżowaniu, Medytacyja przez zmysty o ukrzyżowaniu, Medytacyja przez zmysty o ukrzyżowaniu Pańskim, z jakim żalem byto Panny błogostawionej oraz trzy kolejne: Medytacyja o ukrzyżowaniu przez zmysty i podobieństwo Oblubieñca, Medytacyja o ukrzyżowaniu przez zmysty i podobieństwo Pasterza i Medytacyja o ukrzyżowaniu przez zmysty i podobieństwo Baranka.

W Medytacyi przez zmysty o ukrzyżowaniu już na samym początku zachęca się duszę ludzką do uruchomienia zmysłu wzroku:

I. Poglądać na Zbawiciela Twego przybitego na drzewie krzyża, na którym Go trzymają trzy gwoździe żelazne z Jego okrutną boleścią, tak że ani nogi rękom nie dają żadnego ratunku, ani ręce nogom, ale wszytko ciało rozciągnione wyzszej przybite w mękach nieznośnych.

(Medytacyja przez zmysty o ukrzyżowaniu)

Sporządzony przez umierającego na krzyżu Chrystusa testament to temat podjęty w punkcie drugim medytacji, nakazującym poruszyć zmysł słuchu:

II. Słuchać umierającego Pana. Pomyślić sobie, jako Chrystus umierając, czynił testament i cokolwiek jedno miał, to wszytko rozdał. Naprzód Ojcu Niebieskiemu oddał ducha swego, ciało oddał ziemi, szateczki oddał katom, błogosławioną Pannę Janowi świętemu, wierne swoje Piotrowi świętemu, Łotrowi raj.

(Medytacyja przez zmysty o ukrzyżowaniu) 
W części rozważającej znaczenie testamentu Jezusa, na mocy którego nawet żołnierzom uczestniczącym w egzekucji dostały się szaty Zbawiciela, w wykładni rozszerzającej znalazła się skierowana do Chrystusa prośba duszy ludzkiej, by Jego rany mogła mieć za „spuściznę". One bowiem będą potrafiły ją uleczyć i otworzyć drogę do wieczności.

W scenie ukrzyżowania Chrystusa swój udział ma także Maryja, czego odzwierciedleniem jest Medytacyja przez zmysty o ukrzyżowaniu Pańskim, z jakim żalem było Panny btogosławionej. W tym dwupunktowym rozmyślaniu, w którym wizualizowane jest uczestnictwo Maryi w cierpieniu Zbawiciela, autorka, dla pełniejszego wyobrażenia opisywanej sytuacji, wzywa adepta do użycia zmysłów wewnętrznych:

I. Patrz okiem wnętrznym na Pannę Naświętszą, jako ona poglądała na Syna swego na krzyżu obnażonego, jaki żal żarzeł się na sercu Jej.

(Medytacyja przez zmysty o ukrzyżowaniu Pańskim. Z jakim żalem było Panny btogostawionej)

Z obnażeniem z szat wiąże się kwestia nagości Chrystusa. Przed ukrzyżowaniem oprawcy zdjęli z Niego szatę wierzchnią oraz tunikę, zadając mu straszliwy ból. Podczas biczowania Chrystus miał jedynie przepaskę na biodrach. Po zdjęciu szat tuż przed ukrzyżowaniem być może przez moment był nawet nagi. W Medytacyi przez zmysty o krzyżowaniu Pańskim pobrzmiewa rozpaczliwy żal Matki, która pragnie przyodziać Jego nagie ciało „zawiciem z głowy”, czyli przepaskąa ${ }^{43}$, jednak jest bezsilna. Rozmyślanie kończy modlitwa błagalna do Bożej Rodzicielki o ludzką wolę współuczestnictwa w ogromie Jej boleści.

Scenę ukrzyżowania Chrystusa unaocznia także Medytacyja o ukrzyżowaniu przez zmysty i podobieństwo Oblubieńca, nawiązująca do Pieśni nad Pieśniami. Zaleca się w niej „patrzeć” na Chrystusa jako na Oblubieńca swego, który chcąc nieustannie przyglądać się Oblubienicy, kazał na swoim ciele uczynić pięć okien przestronnych, czyli pięć ran, a wokół nich polecił wykonać kraty, także utożsamiane z ranami, które ułatwiłyby Mu spoglądanie na Oblubienicę. Wyobrażenie to, zaczerpnięte z Pieśni nad Pieśniami $(2,9)$, potwierdzają zawarte w medytacji słowa: „O których [kratach — K. K.-S.] mówi Oblubienica: »Oto ten, prawi, namilszy mój, stoi za ścianą i patrzy przez okna i kraty“”. W Biblii „stanie” („Oto stoi za naszym murem, patrzy przez okna, zagląda przez kraty”, PnP 2, 9), stanowiące kontrast z „bieganiem” i „skakaniem” („Biegnie przez góry, skacze po pagórkach”, PnP 2, 8), pokazuje, iż energia wykonywanych czynności biegania i skakania przemienia się w energię wpatrywania. Obiektem obserwacji staje się Oblubienica. Intensywność spojrzeń Oblubieńca podkreślona zostaje za pomocą liczby mnogiej zastosowanej do okien i krat, co „mnoży badawcze oczy ukochanego" ${ }^{44}$.

Wyraźne odniesienie do Pieśni nad Pieśniami daje się zauważyć także w punkcie drugim medytacji, w którym nakłania się „uważać i słuchać” głosu Oblubieńca,

\footnotetext{
${ }_{43}$ Zawicie - przykrycie na głowę, przepaska; ubranie głowy, welon - zob. J. Karłowicz, A. Kryński, W. Niedźwiedzki, Stownik języka polskiego, wyd. fotooffsetowe, t. 8, Warszawa 1953, s. 340.

${ }^{44}$ O. Keel, „Pieśń nad Pieśniami”. Biblijna pieśń o mitości, przekł. B. Mrozewicz, Poznań 1997, s. 112.
} 
zapraszającego Oblubienicę do uczestnictwa w Jego bólu — w „dziurach skał” i w „jamie” Jego ran. Podkreśla On przy tym, iż czas do wyruszenia jest korzystny: zima się skończyła oraz chłodna pora deszczowa minęła (zob. Pnp 2, 11). Po zarysowanej sytuacji pojawia się część refleksyjna oraz prośba medytującego, by w chwilach zagrażających mu pokus mógł on schronić się, niczym gołębica przed drapieżnym jastrzębiem, w „dziurach” ran Chrystusowych.

Pełen sensualizmu obraz przedstawia punkt trzeci medytacji, w jakim nakazuje się przystąpić do Oblubieńca i rozważać „łoże krzyża” Zbawiciela, który, jak pisze autorka, rozciągnął swe ręce na krzyżu, by człowieka obłapić, nachylił swą głowę, aby Go można było pocałować.

Anonimowy rękopis Kontemplacyja Męki i śmierci Chrystusa Pana wpisuje się w krąg medytacyjnej prozy pasyjnej. Zawarte w nim rozmyślania o Męce Pańskiej są przejawem chrystocentycznej duchowości i pobożności autorki. Wyraża ona w nich swoją cześć dla ran i krwi Chrystusa przelanej za grzeszny lud. Często wzywa do naśladowania cnót Odkupiciela: dobroci, miłości, cierpliwości i pokory. W medytacjach pasyjnych pojawia się także wątek maryjny, co stanowi wyraz czci, jaką składa się Bożej Rodzicielce.

Medytacje pasyjne zawarte w Kontemplacyi Męki i śmierci Chrystusa Pana, podobnie jak Ćwiczenia duchowne Ignacego Loyoli, skoncentrowane są na Chrystusie. Hiszpański jezuita „zamiast ogólników o czci i służbie Bożej” wolał postawić medytującemu „przed oczy praktyczny, konkretny wzór do naśladowania” ${ }^{45}$. Chciał, by człowiek dosłownie mógł zobaczyć Syna Bożego, wpatrywać się w Jego osobę, słuchać Jego słów, wnikać w Jego czyny ${ }^{46}$. Podobnie postępuje anonimowa autorka Kontemplacyi Męki i śmierci Chrystusa Pana. Pokazuje ona, w jaki sposób poznawać „krok po kroku” sceny z Ewangelii i uczyć się o Męce Pańskiej, a za pomocą zmysłów przeżywać to, czego Zbawiciel doświadczał.

W Kontemplacyi Męki i śmierci Chrystusa Pana nakazuje się nie tylko wyobrazić sobie postać Jezusa umęczonego i wszystkie miejsca, w których przebywał, ale wręcz zobaczyć je. Medytacje zalecają bardzo dokładne „przyglądanie się” każdemu, nawet najdrobniejszemu szczegółowi cierpień Odkupiciela. Posługiwanie się metodą zastosowania zmysłów służy lepszemu poznaniu Boga i Jego tajemnic, ale też często pokazuje samego Chrystusa jako istotę sensualną, posługującą się zmysłami.

Anonimowa autorka medytacji pasyjnych, za przykładem św. Ignacego Loyoli, zalecając formę modlitwy, za pomocą której zmysłami doświadczyć można duchowych tajemnic, akcentuje ich doniosłą rolę w procesie duchowego rozwoju. Zmysły użyte we właściwy sposób przyczyniają się nie tylko do głębszego poznania praw objawionych, ale także do prawidłowego odprawiania ćwiczeń duchowych i wewnętrznego doskonalenia się.

\footnotetext{
${ }^{45}$ Św. Ignacy Loyola, $d z$. cyt., s. 70.

${ }^{46}$ Tamże.
} 


\title{
The Idea of the Application of Senses in Meditations about The Passion Exemplified in a Manuscript Stored at Archive of the Sisters of St. Norbert's Order in Zwierzyniec
}

\begin{abstract}
Summary
This article presents the method of the application of senses presented in anonymous meditations entitled Kontemplacja Męki i śmierci Chrystusa Pana. The manuscript dates back to the XVII century and is stored in the archives of the Sisters of St. Norbert's Order in Cracow, so it is possible to make the thesis that the author of this manuscript belonged to this abbey. Contained in the manuscript are meditations that induce contemplation of The Passion with accommodation of the senses, the method introduced by Ignatius of Loyola, and with co-operation of three spiritual rules: the memory, intellect, and volition in meditation of circumstances of Christ's life and mysteries of faith. Upon the conception of the five spiritual senses wrote Origen as well as Saint Bonaventure.

In the anonymous manuscript the method of application of senses are used mainly in meditations about Christ's Agony in the Garden, the flagellation, Saint Mary's feelings during Christ's lashing, the crowning of thorns and crucifixion. The meditations advice precise "observation" by seeing, hearing, smell, feeling and taste of the suffering of Christ. The article submits that all senses used in meditations in the proper way conduce not only to better knowledge of disclosed laws but also to the regular officiating of spiritual exercises and to interior improvement.
\end{abstract}

